\title{
KAJIAN SIFAT MAGNET TERHADAP SINTESIS NANOPARTIKEL FERIT NiZn DENGAN METODE KOPRESIPITASI
}

\author{
Merry Thressia, Dwi Puryanti, Sri Handani \\ Jurusan Fisika, Fakultas Matematika dan Ilmu Pengetahuan Alam, \\ Universitas Andalas, Padang, Sumatera Barat, Indonesia
}

\begin{abstract}
Nanoparticle synthesis process nickel ferrite zink $\left(\mathrm{Ni}_{1-\mathrm{x}} \mathrm{Zn}_{\mathrm{x}} \mathrm{Fe}_{2} \mathrm{O}_{4}\right)$ of iron sand from the village Surian Muaro Labuh been done by coprecipitation method. Iron sand has been extracted and then dissolved in $\mathrm{HCl}, \mathrm{NiCl}_{2}, \mathrm{ZnCl}_{2}$. The results are mixed with and $\mathrm{NH}_{4} \mathrm{OH}$. The value of $\mathrm{x}$ in $\mathrm{Ni}_{1}$ ${ }_{x} \mathrm{Zn}_{\mathrm{x}} \mathrm{Fe}_{2} \mathrm{O}_{4}$ varies with $\mathrm{x}=0 ; 0.5$ and 1 . Characterization to determine magnetic properties of materials made Vibrating Sample Magnetometer using. The results of the magnetic properties characterization showed that the value of magnetizing decreased from $5.525 \mathrm{emu} / \mathrm{g}$ to $0.284 \mathrm{emu} /$ $\mathrm{g}$ with increasing values of $\mathrm{x}$. Value of remanent magnetization and coercive force is in the range of $0.0659 \mathrm{emu} / \mathrm{g}$ to $1.2899 \mathrm{emu} / \mathrm{g}$ and $75 \mathrm{Oe}$ to $223 \mathrm{Oe}$
\end{abstract}

Keywords: Zinc nickel ferrite nanoparticles, coprecipitation method, properties of zinc nickel ferrite magnet

\section{ABSTRAK}

Proses sintesis nanopartikel ferit nikel zink $\left(\mathrm{Ni}_{1-\mathrm{x}} \mathrm{Zn}_{\mathrm{x}} \mathrm{Fe}_{2} \mathrm{O}_{4}\right)$ dari pasir besi yang berasal dari Desa Surian Kabupaten Muaro Labuh telah dilakukan dengan metode kopresipitasi. Pasir besi yang telah diekstrak kemudian dilarutkan dalam $\mathrm{HCl}, \mathrm{NiCl}_{2}, \mathrm{ZnCl}_{2}$. Hasilnya dicampurkan dengan dan $\mathrm{NH}_{4} \mathrm{OH}$. Nilai $\mathrm{x}$ pada $\mathrm{Ni}_{1-\mathrm{x}} \mathrm{Zn}_{\mathrm{x}} \mathrm{Fe}_{2} \mathrm{O}_{4}$ bervariasi dengan $\mathrm{x}=0$; 0,5 dan 1. Karakterisasi untuk mengetahui sifat magnet bahan dilakukan dengan menggunakan Vibrating Sample Magnetometer. Hasil karakterisasi sifat magnet menunjukkan bahwa nilai pemagnetan menurun dari $5,525 \mathrm{emu} / \mathrm{g}$ kepada $0,284 \mathrm{emu} / \mathrm{g}$ dengan meningkatnya nilai x. Nilai magnetisasi remanen dan daya koersif adalah dalam range $0,0659 \mathrm{emu} / \mathrm{g}$ sampai 1,2899 emu/g dan 75 Oe sampai 223 Oe.

Kata kunci : Nanopartikel ferit nikel zink, Metode kopresipitasi, Sifat magnet ferit nikel zink .

\section{PENDAHULUAN}

Besi merupakan logam yang paling banyak terdapat di alam sebagai unsur yang paling banyak membentuk bumi, yaitu kira-kira 4,7-5\% pada kerak bumi. Kebanyakan besi terdapat dalam batuan dan tanah sebagai oksida besi, seperti oksida besi magnetit $\left(\mathrm{Fe}_{3} \mathrm{O}_{4}\right)$, hematite $\left(\mathrm{Fe}_{2} \mathrm{O}_{3}\right)$, limonet $\left(\mathrm{Fe}_{2} \mathrm{O}_{3} \mathrm{H}_{2} \mathrm{O}\right)$ dan siderit $\left(\mathrm{Fe}_{2} \mathrm{CO}_{3}\right)$. Dalam kehidupan, besi merupakan logam paling biasa digunakan karena banyak terdapat di penjuru dunia dan pengolahannya relatif murah dan mudah serta sifat - sifatnya yang mudah dimodifikasi.

Wilayah Sumatera Barat banyak mengandung cadangan batuan besi, salah satunya adalah di Desa Surian Kabupaten Muaro Labuh. Di sini batuan besi yang telah ditambang kemudian dijual dalam bentuk mentah, sehingga nilai jualnya menjadi rendah. Untuk meningkatkan nilai jualnya dibutuhkan pengolahan lebih lanjut, sehingga harga jualnya menjadi meningkat.

Untuk meningkatkan nilai batuan besi dapat dilakukan dengan menjadikannya sebagai bahan dasar pembuatan nanoparticle $\mathrm{Fe}_{3} \mathrm{O}_{4}$. Teknologi nano, salah satunya dikembangkan dengan bahan dasar partikel magnetik $\left(\mathrm{Fe}_{3} \mathrm{O}_{4}\right)$ yang merupakan mineral golongan oksida yang terbentuk dari perubahan mineral besi. Bahan magnetik ini menjadi kajian menarik, karena memiliki aplikasi yang luas pada bidang industri seperti; keramik, katalis, energy storage, magnetic data storage, ferofluida, maupun dalam diagnosis medis (Bakar dkk, 2007 ). 
Pada beberapa tahun terakhir, sintesis dan studi mengenai besi oksida khususnya magnetite $\left(\mathrm{Fe}_{3} \mathrm{O}_{4}\right)$ menarik perhatian para ilmuwan, karena manfaatnya yang luas dalam bidang sains dan teknologi, sehingga pengembangan material ini sangat dibutuhkan baik menyangkut eksplorasi bahan baku, pengembangan metode sintesis, metode karakterisasi, maupun aplikasinya. Dalam hal bahan baku, tentunya diharapkan menggunakan bahan baku yang mudah di diperoleh dan murah. Sedangkan dalam hal metode, diharapkan dapat dilakukan dengan menggunakan metode yang sederhana. Untuk dapat diaplikasikan pada bidang yang lebih luas dapat dilakukan modifikasi dengan penambahan unsur lain.

Pada kesempatan ini, penelitian dilakukan untuk melihat pengaruh penambahan $\mathrm{NiCl}_{2}$ dan $\mathrm{ZnCl}_{2}$ terhadap terhadap sifat magnet bahan. Untuk mengetahui sifat magnet yang terdapat pada bahan dilakukan karakterisasi dengan metode Vibrating Sample Magnetometer menggunakan alat Vibrating Sample Magnetometer Merk Oxford Tipe $1 \mathrm{~T}$ buatan Jerman..

\section{BAHAN DAN METODA}

Bahan dasar yang digunakan pada kajian ini adalah serbuk besi yang diayak dengan ayakan Mess-200, yang mempunyai keluaran butiran $\pm 75 \mu \mathrm{m}$, sehingga hasil ayakan menjadi cukup kecil dan mudah dilarutkan dengan $\mathrm{HCl}$. Hasil ayakan yang merupakan magnetite $\mathrm{Fe}_{3} \mathrm{O}_{4}$ dipisahkan dengan menggunakan magnet pemanen

Untuk membuat ferit nikel zink disediakan bahan baku yang dibutuhkan yaitu $\mathrm{Fe}_{3} \mathrm{O}_{4}, \mathrm{NiCl}_{2}$ dan $\mathrm{ZnCl}_{2}$. Bahan baku tersebut ditimbang sesuai dengan massa yang telah ditentukan. Proses pencampuran yang dilakukan dalam penelitian ini yaitu dengan proses kimia basah (wet chemical process).

Sintesis partikel nano $\mathrm{Fe}_{3} \mathrm{O}_{4}, \mathrm{NiCl}_{2}, \mathrm{ZnCl}_{2}$ dilakukan dengan metode kopresipitasi, serbuk besi dicuci terlebih dahulu dengan menggunakan aquades, kemudian dilarutkan ke dalam $\mathrm{HCl}$ dan diaduk dengan menggunakan magnetic stirrer pada suhu $70^{\circ} \mathrm{C}$ selama 30 menit. Larutan yang terbentuk disaring dengan kertas saring dan di diamkan selama 30 menit sampai terbentuk larutan filtrat. Kemudian ditambahkan $\mathrm{NH}_{4} \mathrm{OH}$ dan diaduk dengan magnetic stirrer pada suhu $70^{\circ} \mathrm{C}$ selama 30 menit. Hasil reaksi dicuci dengan aquades dan di furnace selama 2 jam. Untuk sampel yang akan dilakukan penambahan PEG-1000, maka PEG-1000 terlebih dahulu dipanaskan pada suhu $100^{\circ} \mathrm{C}$ sampai sampai meleleh dan berbentuk pasta. PEG-1000 yang telah meleleh ditambahkan ke dalam larutan $\mathrm{Fe}_{3} \mathrm{O}_{4}$ dan diaduk dengan magnetik stirer selama 15 menit. Untuk mendapatkan serbuk partikel nano $\mathrm{Fe}_{3} \mathrm{O}_{4}$ sampel dikeringkan dengan furnace dengan suhu 220 ${ }^{0} \mathrm{C}$ selama 2 jam. Serbuk yang dihasilkan dikarakterisasi dengan Vibrating Sampel Magnetometer.

\section{HASIL DAN PEMBAHASAN}

Kurva histerisis untuk sampel $\mathrm{Ni}_{1}$ ${ }_{\mathrm{x}} \mathrm{Zn}_{\mathrm{x}} \mathrm{Fe}_{2} \mathrm{O}_{4}$ dengan variasi $\mathrm{x}$ dari $\mathrm{x}=0, \mathrm{x}=0,5$ dan $\mathrm{x}=1$ ditunjukkan pada lampiran Gambar 4.1. Dari gambar kurva histerisis dapat dilihat peningkatan magnetisasi bahan dengan ditingkatkannya medan magnet. Hal ini menunjukkan bahwa tingkat penyearahan momen magnet meningkat dengan peningkatan medan magnet bagi semua sampel yang diuji. Perubahan magnetisasi yang berlaku secara umum berasal dari spin rotasi atau perpindahan dinding domain. Momen-momen magnet di dalam ferit akan menyearah secara sejajar dengan arah medan magnet. Dapat dilihat bahwa dalam daerah medan magnet rendah magnetisasi meningkat dengan cepat sebelum mencapai suatu nilai yang hampir saturasi dalam range medan yang diterapkan. Proses magnetisasi menjadi saturasi ataupun hampir saturasi yang menjadikan bahan domain tungal berlaku dengan adanya pergerakan dinding domain dan pemutaran domain.

Dari gambar, terlihat bahwa kurva histerisis untuk nilai $\mathrm{x}=0,5$ dan $\mathrm{x}=1$ menunjukkan bentuk yang hampir sama. Kurva histerisis yang dihasilkan berbentuk sempit yang menunjukkan kehilangan energi yang rendah karena luas kurva menyatakan pembebasan energi sebagai panas. Kurva histerisis merupakan fungsi terhadap medan magnet untuk sampel-sampel $\mathrm{Ni}_{1-\mathrm{x}} \mathrm{Zn}_{\mathrm{x}} \mathrm{Fe}_{2} \mathrm{O}_{4}$ dengan $\mathrm{x}=0 ; \mathrm{x}=0,5$ dan $\mathrm{x}=1$. 
Nilai - nilai beberapa kuantitas magnet diperlihatkan pada Tabel 4.1. Dari tabel dapat dilihat bahwa parameter magnet $\mathrm{M}_{\mathrm{S}}$ atau magnetisasi saturasi sampel menunjukkan nilai yang menurun dengan peningkatan substitusi Zink. Fenomena ini sesuai dengan yang diperoleh Velmurugan dkk. (2010) yang juga melakukan sistesis nanopartikel ferit nikel zink. Magnetisasi saturasi untuk sampel nikel ferit $\left(\mathrm{NiFe}_{2} \mathrm{O}_{4}\right)$ pada medan magnet yang diterapkan yaitu 1 Tesla adalah 5,525 emu/g. Sedangkan magnetisasi saturasi untuk sampel $\mathrm{Ni}_{0,5} \mathrm{Zn}_{0,5} \mathrm{Fe}_{2} \mathrm{O}_{4}$ dan $\mathrm{ZnFe}_{2} \mathrm{O}_{4}$ adalah 0,668 $\mathrm{emu} / \mathrm{g}$ dan $0,284 \mathrm{emu} / \mathrm{g}$. Nilai magnetisasi saturasi yang rendah ini berasal dari struktur teras kedudukan nanopartikel dimana penyearahan momen magnet teras spin dikelilingi oleh lapisan permukaan spin glas (Nathani dkk. 2004).

Tabel 4.1 juga memperlihatkan nilai suseptibilitas magnet yang semakin menurun dengan peningkatan konsentrasi $\mathrm{x}$ ataupun dengan peningkatan bahan bukan magnet. Suseptibilitas magnet untuk sampel-sampel dihitung menggunakan persamaan

$$
\chi=\frac{M}{H}
$$

dengan $M$ ialah magnetisasi awal (emu/g) menyatakan medan magnet awal yang diberikan. Untuk nilai permeabilitas magnet dihitung menggunakan persamaan (Cullity 1972)

$\mu=1+4 \pi \chi$

Permeabilitas magnet $(\mu)$ merupakan ukuran ransangan magnet sesuatu bahan terhadap medan magnet yang diberikan. Bahan dengan magnetisasi yang tinggi mempunyai nilai $\mu$ yang tinggi yang menunjukkan interaksi antara momen-momen magnet tinggi.

Dari tabel 4.1 dapat dilihat bahwa nilai permeabilitas magnet dan suseptibilitas magnet mengalami penurunan yang sebanding dengan semakin meningkatnya konsentrasi zink. Dari nilai suseptibilitas magnet yang kecil dan bernilai positif maka sampel dapat dikelompokkan kepada bahan ferimagnet.
Tabel 4.1 Nilai parameter-parameter magnetisasi bagi $\mathrm{Ni}_{1-\mathrm{x}} \mathrm{Zn}_{\mathrm{x}} \mathrm{Fe}_{2} \mathrm{O}_{4}$ dengan $\mathrm{x}=0 ; \mathrm{x}=$ 0,5 dan $\mathrm{x}=1$.

\begin{tabular}{ccccc}
$\begin{array}{c}\text { Variasi } \\
(\mathbf{x})\end{array}$ & $\begin{array}{c}\mathbf{M}_{\mathbf{S}} \\
(\mathbf{e m u} / \mathbf{g}) \\
( \pm\end{array}$ & $\begin{array}{c}\mathbf{M}_{\mathbf{R}} \\
(\mathbf{e m u} / \mathbf{g}) \\
( \pm \mathbf{0 , 0 0 0 1})\end{array}$ & $\begin{array}{c}\chi_{I} \\
( \pm \mathbf{0 , 0 0 0 1})\end{array}$ & $\begin{array}{c}\boldsymbol{\mu}_{\boldsymbol{i}} \\
\mathbf{( \pm} \\
\mathbf{0 , 0 0 1})\end{array}$ \\
\hline 0 & 5,525 & 1,2899 & 0,0033 & 1,041 \\
0,5 & 0,668 & 0,1113 & 0,0003 & 1,004 \\
1 & 0,284 & 0,0659 & 0,0002 & 1,002 \\
\hline
\end{tabular}

\section{KESIMPULAN}

Dari hasil penelitian ini dapat disimpulkan: magnetisasi (M) sampel menurun dengan meningkatkan penambahan Zink, nilai magnetisasi sampel berkisar dari 0,284 emu/g hingga $5,525 \mathrm{emu} / \mathrm{g}$, nilai magnetisasi remanen berkisar dari $0,0659 \mathrm{emu} / \mathrm{g}$ hingga 1,2899 emu/g, dari kurva histerisis yang dihasilkan menunjukkan kehilangan energi yang rendah karena luas kurva menyatakan pembebasan energi sebagai panas.

\section{DAFTAR PUSTAKA}

Bakar M. Abu, W.L. Tan, dan N.H.H. Abu Bakar. 2007, Journal of Magnetism and Magnetic Materials, 314, Hal. 1-6

Cullity, B. D. 1972. Introduction To Magnetic Materials. Reading: Addison-Wesley Publishing Company.

Nathani, H., Gubbala, S. \& Misra, R. D. K. 2004. Magnetic behavior of nickel ferritepolyethylene nanocomposites synthesized by mechanical milling process. Materials Science and Engineering B 111: 95-100.

Velmurugan, K., Venkatachalapathy, V. S. K., Sendhilnathan, S. 2010 Synthesis of nickel zinc iron nanoparticles by coprecipitation technique. Materials Research vol 13 no. 3. 
LAMPIRAN

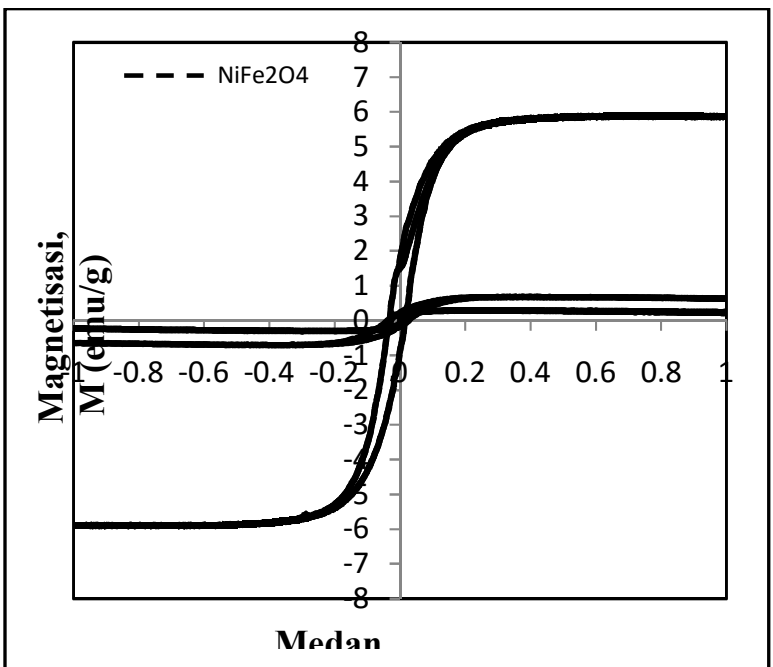

Gambar 4.1, Kurva histerisis sebagai fungsi terhadap medan magnet untuk sampel-sampel $\mathrm{Ni}_{1-\mathrm{x}} \mathrm{Zn}_{\mathrm{x}} \mathrm{Fe}_{2} \mathrm{O}_{4}$ dengan $\mathrm{x}=0 ; \mathrm{x}=0,5$ dan $\mathrm{x}=1$. 